\title{
Front Matter: Volume 8274
}

, "Front Matter: Volume 8274," Proc. SPIE 8274, Complex Light and Optical Forces VI, 827401 (17 February 2012); doi: 10.1117/12.927869

SPIE. Event: SPIE OPTO, 2012, San Francisco, California, United States 


\section{PROCEEDINGS OF SPIE}

\section{Complex Light and Optical Forces VI}

Enrique J. Galvez

David L. Andrews

Jesper Glückstad

Marat S. Soskin

Editors

25-26 January 2012

San Francisco, California, United States

Sponsored and Published by

SPIE

Volume 8274

Proceedings of SPIE, 0277-786X, v. 8274 
The papers included in this volume were part of the technical conference cited on the cover and title page. Papers were selected and subject to review by the editors and conference program committee. Some conference presentations may not be available for publication. The papers published in these proceedings reflect the work and thoughts of the authors and are published herein as submitted. The publisher is not responsible for the validity of the information or for any outcomes resulting from reliance thereon.

Please use the following format to cite material from this book:

Author(s), "Title of Paper," in Complex Light and Optical Forces VI, edited by Enrique J. Galvez, David L. Andrews, Jesper Glückstad, Marat S. Soskin, Proceedings of SPIE Vol. 8274 (SPIE, Bellingham, WA, 2012) Article CID Number.

ISSN 0277-786X

ISBN 9780819489173

Published by

SPIE

P.O. Box 10, Bellingham, Washington 98227-0010 USA

Telephone +1 3606763290 (Pacific Time) · Fax +1 3606471445

SPIE.org

Copyright (C) 2012, Society of Photo-Optical Instrumentation Engineers

Copying of material in this book for internal or personal use, or for the internal or personal use of specific clients, beyond the fair use provisions granted by the U.S. Copyright Law is authorized by SPIE subject to payment of copying fees. The Transactional Reporting Service base fee for this volume is $\$ 18.00$ per article (or portion thereof), which should be paid directly to the Copyright Clearance Center (CCC), 222 Rosewood Drive, Danvers, MA 01923. Payment may also be made electronically through CCC Online at copyright.com. Other copying for republication, resale, advertising or promotion, or any form of systematic or multiple reproduction of any material in this book is prohibited except with permission in writing from the publisher. The CCC fee code is 0277-786X/12/\$18.00.

Printed in the United States of America.

Publication of record for individual papers is online in the SPIE Digital Library.

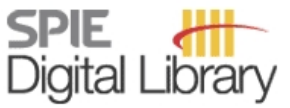

SPIEDigitalLibrary.org

Paper Numbering: Proceedings of SPIE follow an e-First publication model, with papers published first online and then in print and on CD-ROM. Papers are published as they are submitted and meet publication criteria. A unique, consistent, permanent citation identifier (CID) number is assigned to each article at the time of the first publication. Utilization of CIDs allows articles to be fully citable as soon as they are published online, and connects the same identifier to all online, print, and electronic versions of the publication. SPIE uses a six-digit CID article numbering system in which:

- The first four digits correspond to the SPIE volume number.

- The last two digits indicate publication order within the volume using a Base 36 numbering system employing both numerals and letters. These two-number sets start with $00,01,02,03,04$, $05,06,07,08,09,0 A, 0 B \ldots 0 Z$, followed by 10-1Z, 20-2Z, etc.

The CID number appears on each page of the manuscript. The complete citation is used on the first page, and an abbreviated version on subsequent pages. Numbers in the index correspond to the last two digits of the six-digit CID number. 


\section{Contents}

vii Conference Committee
ix Introduction

\section{FUNDAMENTAL OAM}

827403 Mechanically induced image rotation: analogy of the Faraday effect for orbital angular momentum [8274-02]

M. J. Padgett, E. Wisniewski-Barker, G. Gibson, Univ. of Glasgow (United Kingdom);

R. W. Boyd, Univ. of Ottawa (Canada); S. Franke-Arnold, Univ. of Glasgow (United Kingdom)

827404 Cholesteric polymers and the orbital angular momentum of light [8274-03]

W. Löffler, J. P. Woerdman, Leiden Univ. (Netherlands)

827405 Optical superchirality and electromagnetic angular momentum [8274-04]

D. L. Andrews, M. M. Coles, Univ. of East Anglia Norwich (United Kingdom)

827406 Measuring the orbital angular momentum density for a superposition of Bessel beams [8274-05]

A. Dudley, CSIR National Laser Ctr. (South Africa) and Univ. of KwaZulu-Natal (South Africa);

I. Litvin, CSIR National Laser Ctr. (South Africa); A. Forbes, CSIR National Laser Ctr. (South

Africa) and Univ. of KwaZulu-Natal (South Africa)

827407 A higher order Poincare sphere representation [8274-06]

G. Milione, R. R. Alfano, The City College of New York (United States)

OPTICAL FORCES

827408 Current reversals in a deterministic optical rocking ratchet (Invited Paper) [8274-07]

A. V. Arzola, Univ. Nacional Autónoma de México (Mexico) and Institute of Scientific Instruments of the ASCR v.v.i. (Czech Republic); K. Volke-Sepulveda, J. L. Mateos, Univ. Nacional Autónoma de México (Mexico)

QUANTUM SPATIAL: JOINT SESSION WITH CONFERENCE 8272

8274 OC A compact source for quantum image processing with four-wave mixing in Rubidium-85 [8274-11]

U. Vogl, R. Glasser, P. D. Lett, National Institute of Standards and Technology (United States) 
8274 OE Quantum correlations in position, momentum and intermediate bases, measured using fiber arrays (Invited Paper) [8274-13]

F. Izdebski, Heriot-Watt Univ. (United Kingdom); J. Leach, Univ. of Glasgow (United Kingdom); R. E. Warburton, Heriot-Watt Univ. (United Kingdom); D. G. Ireland, Univ. of Glasgow (United Kingdom); S. M. Barnett, A. M. Yao, Univ. of Strathclyde (United Kingdom); G. S. Buller, Heriot-Watt Univ. (United Kingdom); M. J. Padgett, Univ. of Glasgow (United Kingdom)

8274 OF Fiber transport of spatially entangled photons (Invited Paper) [8274-14]

W. Löffler, E. R. Eliel, J. P. Woerdman, Leiden Univ. (Netherlands); T. G. Euser, M. Scharrer, P. Russell, Max Planck Institute for the Science of Light (Germany)

8274 OG Proposal to produce two and four qubits with spatial modes of two photons [8274-15]

E. J. Galvez, Colgate Univ. (United States)

\section{NEW DEVELOPMENTS IN OPTICAL TRAPPING}

$8274 \mathrm{OH} \quad$ Formation of optical flux lattices for ultra cold atoms (Invited Paper) [8274-16]

G. Juzeliūnas, Vilnius Univ. (Lithuania); I. B. Spielman, Joint Quantum Institute (United States)

$827401 \quad$ Optical eigenmodes for imaging applications [8274-17]

S. Kosmeier, M. Mazilu, A. C. De Luca, J. Baumgartl, K. Dholakia, Univ. of St. Andrews (United Kingdom)

8274 0J Bio optofluidics cell sorter: cell-BOCS concept and applications [8274-18]

T. Roth, J. Glückstad, Technical Univ. of Denmark (Denmark)

$8274 \mathrm{OL}$ Laser trapping-induced reconfiguration of individual smectic liquid crystal micro-droplet showing size-dependent dynamics [8274-20]

A. Usman, W.-Y. Chiang, T. Uwada, H. Masuhara, National Chiao Tung Univ. (Taiwan)

\section{NOVEL ASPECTS OF MANIPULATION}

8274 ON Development of a compact bio-optofluidic cell sorter [8274-22]

A. Bañas, D. Palima, F. Pedersen, J. Glückstad, Technical Univ. of Denmark (Denmark)

827400 The Bessel-beam random access trap [8274-23]

T. Paprotta, B. Esembeson, L. Eichner, J. Schumacher, Thorlabs Inc. (United States);

S. C. Wasserman, Massachusetts Institute of Technology (United States); A. E. Cable, Thorlabs Inc. (United States)

\section{COMPLEX LIGHT II: GENERATION AND PROPAGATION}

8274 OR Tailored light fields: nondiffracting and self-similar beams for optical structuring and organization (Invited Paper) [8274-26]

C. Alpmann, M. Boguslawski, P. Rose, M. Woerdemann, C. Denz, Univ. of Muenster (Germany) 
8274 OS Fine topological structure of coherent complex light created by carbon nanocomposites in LC [8274-27]

V. V. Ponevchinsky, Institute of Physics (Ukraine); A. I. Goncharuk, F.D. Ovcharenko Institute of Biocolloidal Chemistry (Ukraine); S. S. Minenko, L. N. Lisetskii, N. I. Lebovka, M. S. Soskin, Institute for Scintillation Materials (Ukraine)

8274 OT Nonlinear mixing of optical vortices [8274-28]

S. Residori, U. Bortolozzo, INLN, CNRS, Univ. de Nice-Sophia Antipolis (France); F. Lenzini, INLN, CNRS, Univ. de Nice-Sophia Antipolis (France) and Univ. di Firenze (Italy); F. T. Arecchi, Univ. di Firenze (Italy)

8274 OU Generation of highly confined optical bottle beams by exploiting the photonic nanojet effect [8274-29]

M.-S. Kim, T. Scharf, Ecole Polytechnique Fédérale de Lausanne (Switzerland); S. Mühlig, C. Rockstuhl, Friedrich-Schiller-Univ. Jena (Germany); H. P. Herzig, Ecole Polytechnique Fédérale de Lausanne (Switzerland)

8274 OV Experimental control over soliton interaction in optical fiber by pre-shaped input field [8274-30]

E. R. Andresen, Institut Fresnel, CNRS, Aix-Marseille Univ. (France); J. M. Dudley, Lab. d'Optique P.M. Duffieux, Institut FEMTO-ST CNRS (France); D. Oron, Weizmann Institute of Science (Israel); C. Finot, Lab. Interdisciplinaire Carnot de Bourgogne, CNRS, Univ. de Bourgogne (France); H. Rigneault, Institut Fresnel, CNRS, Aix-Marseille Univ. (France)

\section{POLARIZATION SINGULARITIES AND VECTOR BEAMS}

8274 OW Tangled nonlinear driven chain reactions of all optical singularities (Invited Paper) [8274-31] V. I. Vasil'ev, M. S. Soskin, Institute of Physics (Ukraine)

8274 OY Poincaré modes of light [8274-33]

E. J. Galvez, S. Khadka, Colgate Univ. (United States)

\section{POSTER SESSION}

$82740 Z$ Enhanced near-field properties of a gap of $\mathrm{TiO}_{2}$ nanosphere pairs for 3D photocatalytic optical trap [8274-34]

T. Honda, M. Terakawa, M. Obara, Keio Univ. (Japan)

827410 Tracking phase singularities in optical fields [8274-35]

J. Borchardt, M. Duparre, S. Skupin, Friedrich-Schiller-Univ. Jena (Germany)

827412 Observation of speckle instability in Kerr random media [8274-37]

S. Residori, U. Bortolozzo, INLN, CNRS, Univ. de Nice-Sophia Antipolis (France); P. Sebbah, Institut Langevin (France)

827414 Diffraction characteristics of optical and polarization vortices generated by an axially symmetric polarizer [8274-39]

M. Sakamoto, K. Oka, R. Morita, Hokkaido Univ. (Japan) 
827415 Broadband orbital angular momentum manipulation using liquid crystal thin films [8274-41] Y. Li, J. Kim, M. J. Escuti, North Carolina State Univ. (United States)

Author Index 


\title{
Conference Committee
}

\author{
Symposium Chair
}

Klaus P. Streubel, OSRAM GmbH (Germany)

Symposium Cochairs

David L. Andrews, University of East Anglia Norwich (United Kingdom) Liang-Chy Chien, Kent State University (United States)

Program Track Chair

Zameer U. Hasan, Temple University (United States)

\section{Conference Chairs}

Enrique J. Galvez, Colgate University (United States)

David L. Andrews, University of East Anglia Norwich (United Kingdom)

Jesper Glückstad, Technical University of Denmark (Denmark)

\section{Conference Cochair}

Marat S. Soskin, Institute of Physics (Ukraine)

\section{Program Committee}

Nicholas P. Bigelow, University of Rochester (United States)

Shu-Chun Chu, National Cheng Kung University (Taiwan)

Kishan Dholakia, University of St. Andrews (United Kingdom)

Wolfgang A. Ertmer, Leibniz Universität Hannover (Germany)

Jean-Marc R. Fournier, Ecole Polytechnique Fédérale de Lausanne (France)

David G. Grier, New York University (United States)

Ruediger Grunwald, Max-Born-Institut für Nichtlineare Optik und Kurzzeitspektroskopie (Germany)

Gerard Nienhuis, Universiteit Leiden (Netherlands)

Miles J. Padgett, University of Glasgow (United Kingdom)

Monika A. Ritsch-Marte, Medizinische Universität Innsbruck (Austria)

Halina H. Rubinsztein-Dunlop, The University of Queensland (Australia)

Grover A. Swartzlander, Jr., Rochester Institute of Technology (United States)

Juan P. Torres, ICFO - Instituto de Ciencias Fotónicas (Spain)

Ewan M. Wright, College of Optical Sciences, The University of Arizona (United States) 


\author{
Session Chairs \\ 1 Fundamental OAM \\ Enrique J. Galvez, Colgate University (United States) \\ 2 Optical Forces \\ David L. Andrews, University of East Anglia Norwich (United Kingdom) \\ 3 Quantum Spatial: Joint Session with Conference 8272 \\ Enrique J. Galvez, Colgate University (United States) \\ $4 \quad$ Quantum Imaging: Joint Session with Conference 8272 \\ Philip R. Hemmer, Texas A\&M University (United States) \\ $5 \quad$ New Developments in Optical Trapping \\ Miles J. Padgett, University of Glasgow (United Kingdom) \\ 6 Novel Aspects of Manipulation \\ Marat S. Soskin, Institute of Physics (Ukraine) \\ 7 Complex Light I: Knots and Vortices \\ Marat S. Soskin, Institute of Physics (Ukraine) \\ 8 Complex Light II: Generation and Propagation \\ Monika A. Ritsch-Marte, Medizinische Universität Innsbruck (Austria) \\ 9 Polarization Singularities and Vector Beams \\ Jesper Glückstad, Technical University of Denmark (Denmark)
}




\section{Introduction}

This year marked the sixth edition of the conference on Complex Light and Optical Forces that is part of Photonics West. We had a record number of submissions, indicative of the rising visibility and stature of the conference. Indeed, this conference is the only yearly venue worldwide for presenting research on complex light. In addition, due to the increasing amount of research in using complex light in quantum information, we organized two joint sessions with the conference on Advances in Photonics of Quantum Computing, Memory, and Communication V.

The conference had two full days of sessions with the following titles: Fundamental OAM; Optical Forces; New Developments in Optical Trapping; Complex Light I: Knots and Vortices; Complex Light II: Generation and Propagation; and Polarization Singularities and Vector Beams. The joint sessions had the titles Quantum Spatial and Quantum Imaging. The conference featured 43 presentations, which include 11 invited presentations, 25 contributed, and 7 posters. These numbers include the joint sessions, which had invited and contributed talks from both conferences.

The present volume is representative of the conference, containing new findings, theories, and experimental results. They highlight current interest and debate on the fundamentals of spin-orbit coupling and experimental tests to observe its manifestations. Other aspects of polarization and spatial modes of light are revisited with presentations on the generation and propagation of polarization singularities, including Poincare beams. The generation and propagation of complex light beams features articles on the propagation of optical vortices in free space, nonlinear media, liquid crystals, and optical fibers; and the generation and propagation of other high-order beams, such as Bessel beams. A huge application of complex light is its ability to exert forces. Articles in this volume feature aspects of manipulation that range from fundamental contributions, on new ways to exert forces with various types of beams and light patterns, to applied, including efforts to create self-contained devices that manipulate and sort. Finally, the presence of complex light in quantum information is highlighted by articles on the generation of spatial entangled states, squeezed states, and the ongoing research in sorting spatial states of photons.

In summary, the present volume is representative of a growing field of photonics that has contributed much to our understanding of light and its applications in manipulation, and which remains leaving much promise of more to come. 
Downloaded From: https://www.spiedigitallibrary.org/conference-proceedings-of-spie on 26 Apr 2023

Terms of Use: https://www.spiedigitallibrary.org/terms-of-use 